A N N A L ES

UNIVERSITATIS MARIAE CURIE-SKŁODOWSKA

LUBLIN - POLONIA

VOL. LXVI, 2

SECTIO G

2019

Uniwersytet Jagielloński w Krakowie

ANNA CEGLARSKA

anna.ceglarska@uj.edu.pl

ORCID: 0000-0003-0868-6097

\title{
Wojna czy pokój? Nowy świat wartości w dziełach Homera
}

War or Peace? A New World of Values in the Works of Homer

Najstarszym znanym nam poematem w kręgu kultury europejskiej jest utwór poświęcony wojnie. Wojna ta warta była tego, by zaledwie kilkudziesięciu dniom poświęcić ponad 15 tys. wierszy zawartych w 24 pieśniach $^{1}$. Zgodnie z przekazem mitologicznym w dziesięcioletnich zmaganiach udział wzięli wszyscy najważniejsi herosi, a niejednokrotnie także bogowie. Wzmiankowaną wojną jest oczywiście wpół mityczna, wpół historyczna wojna trojańska przedstawiona w Iliadzie, której autorstwo przypisuje się Homerowi². Wystarczy spojrzeć jedynie na tytuły poszczególnych pieśni, którymi posługujemy się współcześnie, by założyć, iż wojna jest głównym tematem tego dzieła. Spośród 24 pieśni przynajmniej 16 jest poświęcone kwestiom militarnym. I tak pieśń II przedstawia słynny Katalog Okrętów, czyli sił greckich, które przybyły pod Troję, oraz nieco mniej znany Katalog Trojan i ich sojuszników, natomiast pieśń IV opisuje przegląd wojsk dokonywany przez Agamemnona. Pieśni III, VII i XXII relacjonują pojedynki najważniejszych herosów: Menelaosa z Parysem, Hektora z Ajasem i wreszcie Achillesa z Hektorem. Księgi V, XI, XVI, XVII, XXI i XXII w znacznej części

1 Podział na pieśni jest późniejszy, ponieważ został wprowadzony przez filologów aleksandryjskich. Odwołuję się jednak do niego, gdyż ułatwia systematyzację treści przedstawionych w Iliadzie oraz podkreśla główne wątki akcji.

2 W niniejszym artykule nie poruszam wątpliwości związanych z tzw. kwestią homerycką, czyli próbą ustalenia okresu życia tudzież w ogóle istnienia poety imieniem Homer, a także jednoznacznego określenia autorstwa przypisywanych mu eposów. Pozostaje to poza zakresem analizy, która koncentruje się na przekazie zawartym w tekście dzieła. Na jej potrzeby przyjmuję teorię najpowszechniejszą, iż to rzeczywiście Homer jest autorem Iliady oraz Odysei. Szerzej na ten temat zob. A. Ceglarska, Polityka i sprawiedliwość w Grecji przedsokratejskiej, Warszawa 2019, s. 31-34. 
zostały poświęcone wybitnym czynom greckich wodzów i herosów dokonywanym podczas bitew, a pieśni VIII, XII, XIII i XV opisują konkretne potyczki przy obozie greckim. Wreszcie w pieśni XX nawet bogowie sposobią się do bitwy, którą kontynuują w kolejnej księdze. Stałymi motywami są narady wojskowe (jedna z nich otwiera zresztą akcję Iliady), rozmowy dowódców czy rozważania dotyczące wojny i przyszłości jej uczestników. Co więcej, poeta raczy czytelnika dość plastycznymi opisami potyczek: włócznia Achillesa roztrzaskuje kości głowy i mózgiem plami na wskroś wszystko ${ }^{3}$, ranni chwytają swoje wnętrzności, płynie krew gęsta i czarna ${ }^{4}$, rdzeń tryska z przerąbanych kręgów ${ }^{5}$. Można zatem z łatwością ulec przekonaniu, iż na kartach Iliady wojna jest nie tylko gloryfikowana, ale sama wręcz jest osobną, najważniejszą bohaterką homeryckiego eposu. Tę dość powszechną opinię, jakoby Homer miał sławić wojnę i przedkładać zmagania wojskowe nad czasy pokoju, pragnę podważyć w niniejszym opracowaniu. W obu przypisywanych poecie dziełach pojawia się bowiem wyraźna krytyka nie tylko samej wojny, ale i ogólniej - przemocy mającej stanowić sposób rozwiązywania konfliktów, chwalone są zaś czasy pokoju i spokojne życie.

Tradycja uznawania autora Iliady i Odysei za poetę gloryfikującego wojnę oraz chwałę zdobywaną na polu bitwy i bohaterstwo herosów sięga czasów starożytnych i legendarnej rywalizacji Homera z drugim słynnym poetą - pochodzącym z Beocji Hezjodem. Poświęcony jej poemat Certamen Homeri et Hesiodi (czyli $O$ wspótzawodnictwie Homera i Hezjoda) przedstawia poetycki pojedynek pomiędzy dwoma aojdami ${ }^{6}$. Oczywiście Certamen nie jest źródłem historycznym, daje jednak dość dobre wyobrażenie na temat tego, jak niegdyś interpretowano dzieła Homera. Gdy na zakończenie opisanego we wspomnianym poemacie agonu obaj poeci wygłosili fragmenty swoich wierszy, publiczność jednoznacznie opowiedziała się za Homerem. Jednakże organizator igrzysk wygraną przyznał Hezjodowi, gdyż ,jest rzeczą słuszną, by zwyciężył ten, kto nawołuje do uprawy roli i pokoju, a nie ten, kto sławi walki i rzezie"7. Wyrok ten (który zresztą stał się synonimem złego rozstrzygnięcia) ${ }^{8}$, niezależnie od jego słuszności oraz preferencji artystycznych sędziego, jest moim zdaniem przede wszystkim całkowicie błędnie uzasadniony, a zastosowana argumentacja, jakoby Homer wyłącznie „sławił walki i rzezie", nie sugerując rozwiązań pokojowych, świadczy o pobieżnej znajomości i niezbyt wnikliwej interpretacji dzieł poety. Wbrew pozorom Homer

3 Homer, Iliada, Warszawa 2005, XX, 400, dalej jako: Il.

4 Il., XI, 813, 845; Il., XVII, 51; Il., XIII, 539; Il., XX, 470; także w porównaniach: Il., XVIII, 583.

Il., XX, 482.

6 O Homerze i Hezjodzie, ich pochodzeniu i wspótzawodnictwie [Certamen Homeri et Hesiodi], [w:] Homeriká, czyli żywoty Homera i poematy przypisywane poecie, oprac. W. Appel, Warszawa 2007 , s. 43-61.

7 Ibidem, s. 55.

8 Ibidem, przypis 58. 
bowiem nie gloryfikuje wojny i bezmyślnej przemocy, wręcz przeciwnie - prawdziwą wartość ma dlań ludzkie życie. Przykłady tego stanowiska można odnaleźć w obu jego dziełach - zarówno w Iliadzie, jak i Odysei.

Wyjątkowo oczywiste jest ono w tym drugim poemacie. W czasie trwania akcji Odysei na świecie trwa pokój. Większość greckich wodzów (oprócz nieszczęsnego Odyseusza) zdołała już powrócić do domów; część z nich ponownie objęła swe krainy we władanie i sprawowała sprawiedliwe rządy. Do dwóch takich władców: Nestora i Menelaosa, udaje się Telemach, syn Odysa, poszukując ojca. W obu miastach odbywają się ważne uroczystości: w Pylos składane są ofiary, w Sparcie zaś trwa wesele. Obaj królowie potrafią docenić fakt, iż mogą cieszyć się pokojem i beztroską wraz ze swymi obywatelami. Nestor wspomina: „Tam padło tylu najlepszych! [...] i jeszcze więcej klęsk przyszło nam wycierpieć [...] nawet gdybyś tu pozostał pięć albo sześć lat i wypytywał o wszystko, co wycierpieli boscy Achajowie - zanimby skończył, już byś umęczony chciał wrócić do ziemi ojczystej”’. Dalej odnajdujemy jeszcze wyraźniejszą krytykę minionej, długoletniej wojny, którą wygłasza sam Menelaos: „Chciałbym mieć tylko trzecią część tego, co posiadam, ale żebym się nie był ruszał z domu i żeby żywi byli mężowie, co zginęli na równinie trojańskiej [...]. Często ich wszystkich boleśnie opłakuję"10.

Co znamienne, władca Sparty zmienił swe poglądy dopiero po zdobyciu Troi i odzyskaniu małżonki, ponieważ podobne słowa wygłosił jeszcze w Iliadzie („Trzeba zakończyć te spory / Trojan i dzielnych Argiwów. / Dość zła wszyscy doznali / Przez Aleksandra i moją niezgodę" ${ }^{11}$ ) w chwili, gdy zdecydował się stoczyć pojedynek z głównym sprawcą nieszczęść - Parysem, aby ostatecznie rozwiązać konflikt. Główny poszkodowany - ten, od którego można by oczekiwać, iż będzie chciał walczyć do ostatniej kropli krwi - nie wysławia wojennej chwały, aby przekonać towarzyszy do dalszych ataków, lecz hołduje zupełnie innym wartościom i pragnie położyć kres przemocy. Czy można znaleźć bardziej wyrazistą pochwałę dla czasów pokoju oraz potępienie zła, jakim jest wojna?

Oprócz podróży Telemacha drugim głównym motywem Odysei jest powrót bohatera wojny trojańskiej, nieszczęsnego Odyseusza, do rodzinnej Itaki. Co ciekawe, tragizm tej wędrówki jest podkreślany przede wszystkim poprzez cierpienie Odyseusza wywołane utratą towarzyszy podróży ${ }^{12}$ oraz akcentowanie faktu,

9 Homer, Odyseja, Warszawa 1998, III, 103-117, dalej jako: Od.

10 Od., IV, 97-100.

11 Il., III, 98-100.

12 Przekleństwo rzucone nań przez Cyklopa również głosi, iż Odys ma powrócić „późno i w nędzy”, przy czym jako pierwszy przykład tejże wymienia właśnie utratę załogi, a nie zdobytych skarbów. Przybywając do Feaków, Odyseusz również podkreśla zgubę, która spotkała wszystkich towarzyszy po tym, jak ich okręt zatonął (Od., IX, 532-535; Od., VII, 251). Śmierć szlachetnych wojowników wielekroć jest przez Homera przywoływana jako negatywny aspekt wojny i największa strata. Zob. O Homerze i Hezjodzie, ich pochodzeniu..., przypis 8 i n. 
że przebywa on z dala od ukochanych osób ${ }^{13}$. Nigdy w trakcie swej tułaczki Odys nie zapragnął raz jeszcze stanąć w szranki, by wykazać się odwagą i powiększyć swą chwałę; jest wręcz przeciwnie - za wszelką cenę chce powrócić do domu, porzuconej oazy spokojnego życia, i doczekać starości u boku ukochanej żony oraz syna. Nawet kiedy staje przeciwko zalotnikom, nie stosuje od razu przemocy. Wielekroć wcześniej napominał ich wszakże Telemach, itaccy dostojnicy, a wreszcie sam Odys pod postacią żebraka. Przemoc jest zatem rozwiązaniem ostatecznym i dotyka tylko tych, którzy bezpośrednio złamali obowiązujące zasady, czyli naruszyli prawa gospodarza. Najszlachetniejszy z zalotników, Amfinomos, tuż przed momentem kulminacyjnym otrzymuje od przebranego za żebraka Odyseusza jeszcze jedną szansę ocalenia życia, lecz odrzuca ją, akceptując nieuchronny $\operatorname{los}^{14}$. Nadchodzący konflikt w postaci wojny domowej, do której podżega Eupejtes, ojciec jednego z zalotników, zostaje natomiast błyskawicznie zażegnany poprzez usunięcie przywódców oraz interwencję bogów, co również podkreśla, iż nawet sami Olimpijczycy bardziej cenią sobie pokój niż krwawe potyczki.

Pozornie zaprzecza temu XXI pieśń Iliady opisująca właśnie walkę bogów. Warto jednak zauważyć, iż spośród stających w szranki wielu rezygnuje z bezpośredniego stosowania przemocy, oddając zwycięstwo na zasadzie starszeństwa lub potęgi swym przeciwnikom. Spośród wymienionych przez poetę pojedynkujących się $\operatorname{par}^{15}$ nawet najzagorzalszy stronnik Trojan, Apollo, unika konfrontacji z Posejdonem, stwierdzając: „,...] byłbym niespełna rozumu, jeślibym z tobą wiódł wojnę z przyczyny nędznych śmiertelnych", ponieważ - jak wyjaśnia Poeta - „wstyd by mu było zetrzeć się z bratem ojcowskim wręcz w bitwie nieubłaganej"16. W starciu biorą udział jedynie bogowie, których konflikt dotknął bezpośrednio (np. znana skądinąd ze swego porywczego charakteru Hera oraz Afrodyta, która w znacznej mierze przyczyniła się do wybuchu wojny), oraz ci bezpośrednio związani z wojną, czyli Ares i Atena. Mimo że Walter Leaf w swoim komentarzu do Iliady stwierdził, iż nie da się wskazać żadnej oczywistej zasady wyboru przeciwników ${ }^{17}$, znamienne wydaje mi się zestawienie Ateny z Aresem oraz wynik tego starcia. Wprawdzie oboje związani są z wojną, lecz ucieleśniają

13 Od., VII, 153. Odys godzi się wręcz więcej cierpieć, a nawet zginąć, „bylebym wprzód zobaczył mój dobytek, moją czeladź, mój dom wysoki” (Od., VII, 224-225).

14 Od., XVIII, 125-155.

15 Zapowiedziane są pojedynki: Apolla z Posejdonem, Enyaliosa (czyli Aresa) z Ateną, Hery z Artemidą, Latony i Hermesa oraz Hefajstosa i Skamandra, boga rzeki (Il., XX, 67-74), przy czym Skamander zostaje do pojedynku sprowokowany zachowaniem Achillesa, który w jego nurtach bezlitośnie pozbawia życia trojańskich młodzieńców (Il., XXI, 216-224, 233-236), a Hefajstos działa na polecenie Hery (Il., XXI, 330-333).

16 Il., XXI, 462-479. Podobnie Hermes odmawia walki z Latoną (Il., XXI, 498).

17 Poza oczywistym antagonizmem Hefajstosa (ognia) i Skamandriosa (wody). Zob. The Iliad, edited, with apparatus criticus, prolegomena, notes, and appendices by W. Leaf, London 1900, 20.67. 
zupełnie inne jej aspekty. Powszechnie uznawany za boga wojny Ares uosabia jej niszczycielskie cechy. To raczej bóg rzezi, przelewu krwi i zniszczenia. Sam Zeus oskarża go słowami: ,Jesteś mi wrogi najbardziej ze wszystkich bogów Olimpu, / miła ci bowiem jest zawsze niezgoda, bitwa i wojna"18.

Atena również kojarzona jest $\mathrm{z}$ wojną. Opis jej narodzin głosi, iż wyskoczyła z głowy swego ojca Zeusa od razu w pełnym rynsztunku, potrząsając włócznią. W sztuce najczęściej była przedstawiana w wojskowym hełmie na głowie, często przyodziana w pancerz. Ponadto jest jednak personifikacją mądrości i tym samym uosabia zupełnie inny aspekt rzeczywistości, ponieważ jej cechy umożliwiają jej działanie zarówno w trakcie wojny, jak i pokoju. Podczas gdy Ares jest niszczycielem, ona została nazwana patronką miast (Polias) oraz „walczącą w pierwszych szeregach" (Promachos), jest zarazem Mocną (Sthenias) i Pracownicą (Ergane) ${ }^{19}$. W przeciwieństwie do Aresa Atena nie tylko potrafi niszczyć, ale też tworzyć i budować. Epitety wojenne uzupełniają się z tymi, które sugerują pokojowe współżycie. Atena wspiera tych, których obiecała chronić - czy to Greków pod Troją, czy wybranych herosów, natomiast Ares szuka wyłącznie bitewnego chaosu - nie ma żadnego bohatera, któremu byłby przewodnikiem, a w wojnie trojańskiej obiecał pomoc obydwu stronom ${ }^{20}$. Atena jest przywódczynią w bitwie i w radzie, z kolei Ares przypomina wpadającego w szał berserkera, który oprócz swej siły (a raczej czystej agresji) nie może niczego społeczności zaoferować. Ich konfrontacje kończą się zresztą zawsze zwycięstwem Ateny. W pieśni V pokonuje go wspierany przez boginię Diomedes, w pieśni XXI zaś wybawia go z opresji Afrodyta. Ares - uosobienie wojny okrutnej, krwawej, zażartej - zostaje zatem nie tylko pokonany, ale i upokorzony. Najpierw rani go śmiertelnik, a potem ratuje najsłabsza spośród bogiń. Na placu boju zostaje dumna Atena. Co ciekawe, to właśnie ta bogini stanie się w późniejszych wiekach patronką nowego, pokojowego sposobu rozstrzygania sporów na drodze sądowej. To jej głos przyczyni się do uwolnienia Orestesa od zmazy matkobójstwa, a poprzez to do obłaskawienia straszliwych Erynii i ich przekształcenia w Eumenidy, Panie Łaskawe, strażniczki sprawiedliwości. Sam Ares nigdy nie uznał drogi procesowej. Jak głoszą mity, przed sądem stanął zaledwie raz - pozwany przez pozostałych bogó $\mathrm{w}^{21}$. Pozostawał w ten sposób bóstwem jednowymiarowym, nieprzydatnym w czasach pokoju, ale i podczas wojen jego wpływy nie były oceniane pozytywnie; poddanie się Aresowemu szaleństwu bitewnemu przez śmiertelników również nie spotykało się z uznaniem bogów. Honorowe pojedynki były toczone w określony sposób. Poprzedzało je

18 Il., V, 890-891.

19 Z. Kubiak, Mitologia Greków i Rzymian, Warszawa 2003, s. 225.

${ }^{20}$ Co zresztą wypomina mu Atena, określając go mianem szaleńca: „[...] co wspiera jednych i drugich - / Herze i mnie tak niedawno uroczystymi słowami / Przyrzekł iść przeciw Trojanom, a wspomóc w walce Argiwów, / teraz pomaga Trojanom, a o Achajach zapomniał” (Il., V, 831-834).

21 R. Graves, Mity greckie, Kraków 2012, s. 60. 
wyzwanie, a pokonany mógł próbować się wykupić. Miały one na celu nie tyle zagładę, ile porównanie sił, dlatego przeciwnicy często darzyli się szacunkiem i podziwem. Pragnienie chwały i reguły wojenne ustępowały także przed innymi, ważniejszymi wartościami. Gdy w pieśni VI na polu bitwy Diomedes i Glaukos odkrywają łączące ich więzi wynikające z dawniej udzielonej przez ich ojców gościny, rozstają się w pokoju, by nie naruszać fundamentalnego i bardziej cenionego prawa gościnności²2. Kiedy zaś kilka pieśni później Achilles powraca do bitwy i w szale zabija każdego przeciwnika, nie bacząc na jego ród, wiek bądź próby ocalenia życia w zamian za okup, wzbudza to gniew bogów - w tym wypadku Skamandriosa, którego wody plugawione są takim działaniem ${ }^{23}$. Nie tak bowiem winny odbywać się potyczki toczone przez herosa. W ten sposób wygląda rzeź sprowadzana przez Aresa, a on wszakże wstrętny jest wszystkim. Iliada zatem nie krytykuje heroicznych wartości ${ }^{24}$, takich jak honor czy odwaga, lecz bezmyślną przemoc i niepotrzebne okrucieństwo.

Znamienne jest w tej sytuacji także zachowanie Zeusa, który podczas starcia bogów nie angażuje się po żadnej ze stron, tylko śmieje się, „gdy bogów zobaczył przygotowanych do walki" ${ }^{25}$. Później odwraca swój wzrok od toczących się potyczek pod Troją i spogląda ku spokojnej krainie Etiopów, by nie patrzeć na okrucieństwa wojny. W opisie walki bogów jest też wiele elementów komicznych - bóstwa nie zachowują się tak, jak moglibyśmy oczekiwać po bytach „wyższego rzędu", lecz obrzucają się obelgami i kpią z siebie nawzajem, przedrzeźniają się, zranieni wybuchają płaczem i uciekają. Nie są to więc żadne chwalebne pojedynki w obronie nieszczęsnych ludzi, wręcz przeciwnie - Homer drwi z walki bogów, przedstawiając ją niemal jak przepychanki dzieci, które kłócą się o jakiś drobiazg, podczas gdy ojciec patrzy na nie $\mathrm{z}$ wyrozumiałością. W ich próbie siłowego rozwiązania konfliktu nie ma zatem niczego godnego podziwu. Prawdziwie godnie zachowują się ci, którzy - jak Apollo i Hermes - są w stanie odstąpić od pojedynku, uznając siłę tudzież dostojeństwo przeciwnika. Poeta nie zarzuca im tchórzostwa, lecz wyraźnie podkreśla ich wyższość nad pozostałymi. Drobne spory (w tym wypadku wojna toczona przez śmiertelników) nie powinny bowiem wpływać na relacje pomiędzy bogami, a na pewno nie powinni oni swoich konfliktów rozwiązywać w ten sam sposób. Przenosząc tę naukę na relacje pomiędzy ludźmi, Homer także im sugeruje, aby najpierw sięgnąć po środki pokojowe (a czasem nawet ustąpić), ponieważ uciekając się do prostej, prymitywnej siły, przypominają raczej swarliwe dzieci niż szlachetnych wojowników, którzy chcą rozwikłać spór.

22 Il., VI, 215-231.

23 Il., XXI, 214-221.

24 Taką też (słuszną) tezę postawił w swoim artykule A.W.H. Adkins (Values, Goals, and Emotions in the Iliad, "Classical Philology" 1982, Vol. 77(4), DOI: https://doi.org/10.1086/366728, s. 321).

25 Il., XXI, 390. 
Dopełnieniem tego obrazu jest sposób przedstawienia dwóch największych bohaterów wojny trojańskiej stojących po przeciwnych stronach barykady: Hektora i Achillesa. Są to herosi, bohaterowie niemal idealni, których imiona - właśnie dzięki tej wojnie - na wieki zapiszą się w historii. Trwający konflikt nie cieszy jednak żadnego z nich. Hektor wprost głosi, iż musi walczyć, by bronić swej ojczyzny. Nie ma nic godniejszego niż śmierć w jej obronie, co bynajmniej nie oznacza, że tej śmierci pragnie. Kilkakrotnie w trakcie starć były podejmowane kroki mające na celu zakończenie konfliktu z jak najmniejszymi stratami po obu stronach: poselstwa, rokowania oraz pojedynki. Ostatni z nich stoczył sam Hektor z Ajasem, wcześniej zaś rozstrzygnięcie miał przynieść bój bezpośrednio zainteresowanych losami Heleny, czyli Menelaosa z Parysem. Tak się jednak nie stało. Hektor jest w dużej mierze bohaterem tragicznym - nie ma wyboru, musi walczyć w obronie swojego miasta i rodaków, mając świadomość, że zapewne czeka go śmierć. Konsekwencje wojny obrazowo zostały przedstawione w przejmującej scenie pożegnania Hektora z Andromachą - mieszkańcy Troi poniosą śmierć, Andromacha najpewniej stanie się niewolnicą któregoś ze znaczących Greków, a ich syn będzie pogardzanym przez innych sierotą ${ }^{26}$. Sam Astyanaks również nie zachowuje się tak, jak można by oczekiwać po potomku herosa - nie cieszy się na widok gotowego do boju ojca, a przerażający hełm z kitą powoduje, że wybucha płaczem. Dziecko instynktownie zdaje się pojmować, że prawdziwa wojna jest strasznym wydarzeniem.

Co znamienne, wszelkie wątpliwości dotyczące słuszności działań wojennych i przedkładania ich nad życie w pokoju najdosadniej i wprost wyrażone są przez samego Achillesa - ucieleśnienie herosa, bohatera idealnego, który wygrywa wszelkie potyczki i skazany jest na wieczną chwałę. Słowo ,skazany” nie jest tu użyte przypadkowo. Achilles to postać całkowicie tragiczna. Nie był związany żadną przysięgą, która mogłaby zobowiązać go do walki o Helenę. Nie był lennikiem któregokolwiek z władców, by mieć obowiązek się stawić. Przybywa, podstępem zwabiony przez Odysa, w poszukiwaniu chwały; chwałę tę zresztą początkowo uzyskuje, gdyż staje się najstraszliwszym z greckich wojowników, na dźwięk jego imienia drżą Trojanie, zdobywa liczne pomniejsze grody i gromadzi wiele łupów. Jego sytuacja ulega zmianie, gdy część tej chwały zostaje mu odebrana i to nie przez wroga, lecz przez sojusznika - głównego dowódcę wojsk greckich, Agamemnona. Władca Myken bowiem zabiera mu niewolnicę Bryzejdę, na co Achilles nie może tak po prostu przystać. Istotny w tym wypadku jest nie tyle jego osobisty sentyment do branki, co fakt, że była ona jego łupem, nagrodą, którą otrzymał od Achajów, a nie od samego Agamemnona; była widomym znakiem jego wojennego bohaterstwa, chwały, jaka go otaczała, oraz czci, którą darzyli go Grecy ${ }^{27}$. Achilles jest przecież nie tylko królewskim synem, he-

26 Il., VI, 451-459; Il., XXII, 485-505.

27 Zob. A. Ceglarska, op. cit., s. 56, 73. 
rosem czy półbogiem, ale przede wszystkim najlepszym spośród achajskich wojowników! Agamemnon nie chce potwierdzić należnej mu czci i chwały słowami, przeciwnie - odbiera mu jej widoczny znak, czyli brankę. Tym samym Achilles traci część swojego autorytetu, część chwały herosa. Ten despekt nie może zostać wynagrodzony nawet późniejszą ofertą Agamemnona, który usiłując załagodzić spór i nakłonić Achillesa do powrotu, obiecuje mu dary o wiele cenniejsze od jednej branki. Odrzucenie oferty Agamemnona moim zdaniem wynika jednak z innych przesłanek, niż sugeruje to chociażby James A. Arieti ${ }^{28}$. W jego interpretacji propozycja Agamemnona ma wyrównać Pelidzie utratę honoru. Tymczasem to już nie honor wojownika i chwała są dla Achillesa najważniejsze. Zmieniło się bowiem jego postrzeganie najistotniejszych wartości. Przez dziewięć lat walczył dla Greków i nie uzyskał z tego tytułu adekwatnej zapłaty. Ta sytuacja prowokuje go do zastanowienia się nad własnym postępowaniem. Nie przyjmuje darów Agamemnona, którymi król chciał go przejednać, ponieważ - jak głosi z emfazą - „życia człowieka nie może żadna z wartości przewyższyć”29. Dlatego woli odrzucić perspektywę poślubienia córki władcy Myken oraz możliwość uzyskania w ramach jej posagu licznych grodów i wybiera małżeństwo z „dziewczyną, którą mu ojciec wybierze", którą będzie mógł obdarzyć miłością i osiąść z nią w rodzinnej Fytii. „Tam nieugięta ma dusza często mi z piersi ulata, / pragnąc mieć żonę kochaną i towarzyszkę dni moich - / w domu, gdzie Peleus dostatków dość nagromadził sędziwy" ${ }^{30}$.

W Odysei, kiedy władca Itaki napotka jego cień w Podziemiu, syn Peleusa wygłasza znamienne słowa: „Nie zachwalaj mi śmierci, prześwietny Odysie! Wolałbym za parobka służyć na cudzej roli, niż tu panować nad wszystkimi, co znikli ze świata"31. W treści Iliady próżno szukać sugestii, jakoby życie po śmierci miało być dla herosa lepsze tudzież szczęśliwsze od doczesnego ${ }^{32}$. Zdobyta chwała pozostanie na ziemi, będzie głoszona przez potomnych, lecz sam heros jest skazany na marną egzystencję pośród cieni innych zmarłych. Achilles podaje zatem w wątpliwość istnienie jakichkolwiek korzyści, a przez to i sens wojny: Czy warto umrzeć, zyskując wiekuistą chwałę? Czy warto wdawać się w długotrwałe konflikty zamiast żyć w pokoju? Odyseusz nazywa go najszczęśliwszym człowiekiem na świecie, ponieważ już za życia był czczony jako bohater, po śmierci zaś

28 J.A. Arieti, Achilles' Alienation in 'Iliad 9', “The Classical Journal” 1986, Vol. 82(1), s. 7.

29 Il., IX, 401.

30 Il., IX, 398-400.

31 Od., XI, 487-491.

32 Wyjątkiem jest Menelaos, któremu Proteus przepowiedział, że nie umrze w Argos, lecz zostanie wysłany na Pola Elizejskie, ,gdzie ludzi czeka żywot błogi”. Podał też dodatkowe uzasadnienie takiego stanu rzeczy: „Boś ty dla bogów jest mąż Heleny i zięć Dzeusa” (Od., IV, 561-569). Tak także: C.N. Smiley, Certain Similarities in the Fundamental Thought of the Early Hebrews and the Homeric Greeks, "The Classical Journal” 1926, Vol. 21(5), s. 334. 
włada zmarłymi. Tymczasem Achilles odrzuca tę argumentację. Jego wątpliwości pojawiły się jednak dużo wcześniej. Przez większość czasu w Iliadzie rozdarty jest pomiędzy żądzą chwały, którą może uzyskać tylko na polu walki, a pragnieniem spokojnej, prozaicznej egzystencji w ojcowskim majątku:

Nieraz mi matka mówiła, Tetyda o stopach srebrzystych,
że dwie prowadzą mnie Kery dwiema drogami do śmierci:
jeśli pod grodem trojańskim zostanę, by dalej tam walczyć -
nie ma stąd dla mnie powrotu, lecz sławę wieczną uzyskam;
jeśli do domu powrócę, do mojej ziemi kochanej -
sławy nie zyskam, lecz w zamian życie szczęśliwe i długie
los mi przeznaczy, nieprędko dosięgnę czarnych bram śmierci ${ }^{33}$.

Po latach wybór dla Achillesa wcale nie jest już tak oczywisty. Owszem jako młodzik pragnął nade wszystko chwały, dlatego wyruszył pod Troję. Później jednakże dostrzegł, że chwała ta jest całkowicie ulotna: ,[...] umrze tak samo i próżniak, i mąż, co wiele dokonał"34.

Co więcej, Achilles de facto podjął decyzję - wysłanym przez Atrydę posłom mówi, że gotów jest zepchnąć na wodę okręty, a zatem rzeczywiście powrócić do domu i wieść spokojne życie. Wbrew pozorom do końca nie zmienia tego stanowiska. Kiedy ponownie wyrusza do boju, pokonuje Hektora, a wreszcie ponosi śmierć. Należy podkreślić, że nie czyni tego, ponieważ odzyskał wiarę w sens wojny. Wręcz przeciwnie, utraciła ona dlań cały swój urok. Nie pragnie już chwały ani łupów, lecz zemsty; walczy jedynie dlatego, że zginął jego najbliższy przyjaciel Patroklos i musi go pomścić. Tym samym traci możliwość dokonania faktycznego wyboru, co dodatkowo czyni go bohaterem jeszcze bardziej tragicznym. Wielki wojownik, który odkrył, jak niezwykłą rzeczą może być pokój i ile szczęścia daje spokojne życie, musi stanąć do walki, porzucić swoje marzenia i zgodnie z wyrokami losu ponieść śmierć. Znaczące jest, iż właśnie w tym momencie relacja wydarzeń związanych z toczącą się wojną zostaje przerwana, by zaprezentować czytelnikowi niezwykle detaliczny opis stworzenia przez Hefajstosa nowej zbroi Achillesa, w tym słynnej tarczy. Element ten jest powiązany z głównym wątkiem akcji - wszakże w dawnej zbroi Achillesa zginął Patroklos i została ona potem przejęta przez Hektora. Heros zatem, by móc wrócić do walki, potrzebuje nowej. Jednocześnie opis stworzenia i przyozdobienia tarczy jest zbyt szczegółowy, by być jedynie trywialnym wyjaśnieniem zaistniałej sytuacji mającym umożliwić Achillesowi powrót do boju. Jej opis, jak wskazuje Stephen Scul$1 y^{35}$, został zawarty w tekście nie tyle ze względu na bohaterów, ile na czytelnika.

33 Il., IX, 410-416.

34 Il., IX, 319.

35 S. Scully, Reading the Shield of Achilles: Terror, Anger, Delight, "Harvard Studies in Classical Philology" 2003, Vol. 101, DOI: https://doi.org/10.2307/3658523, s. 29-47. 
Sama tarcza jest nie tylko praktyczna, ale i piękna. To wręcz dzieło sztuki, którym raczej można by się cieszyć w czasach pokoju. W ferworze bitwy ani wojownik, ani wróg nie zdołają docenić jej doskonałości. Przedstawione na niej obrazy nie mają na celu także dodatkowego przerażenia i osłabienia woli przeciwnika. Widać tu wyraźny kontrast z przedstawioną w pieśni XI tarczą Agamemnona:

Z dzikim wejrzeniem Gorgona straszliwie patrząca wieńczyła

Tarczę, a wkoło Gorgony jawił się Popłoch i Trwoga.

Uchwyt przy tarczy był srebrny, a na nim wił się ze stali

Ciemnobłękitnej wąż groźny, co swymi trzema głowami

Chwiał się, choć z jednej wyrosły szyi, na wszystkie w krąg strony ${ }^{36}$.

Na tarczy Achillesa natomiast są przedstawione:

[...] dwa miasta dla mową władnących ludzi, piękne. Z nich w jednym szykują ucztę i gody weselne, [...]

Młodzi pląsają ochoczo, a w korowodzie tanecznym

dźwięczą formingi i flety śpiewne. [...]

W rynku tymczasem przechodnie stanęli ciżbą, bo waśnią

jacyś mężowie tam byli dwaj o zapłatę skłóceni.

[...] starszyzna

w świętym kolisku zasiadła na wygładzonych kamieniach, berła heroldów o głosie donośnym dzierżąc w swych rękach.

Z nimi powstają i każdy z kolei swój wyrok ogłasza. [...]

Wkoło zaś miasta drugiego dwa wrogie wojska leżały

połyskujące zbrojami. [...]

Lecz nie ulegli obrońcy i zbrojnie na nich czyhali.

Drogie małżonki stanęły w obronie murów, nieletnie

dzieci i zgięci pod wieku ciężarem sędziwi mężowie.

Wojsko zaś poszło. Przewodził mu Ares i Pallas Atena.

[...] uformowali swe szyki nad rzeką i bitwa zawrzała.

Jedni na drugich miotali włócznie o grotach spiżowych.

Wtedy spotkały się razem Niezgoda, Popłoch i Kera

zgubę niosąca, co chwyta jednego, gdy został raniony,

chociaż nietknięty - drugiego, trzeciego za nogi wywleka

w zgiełku. Jej szata w krąg ramion czerwieni się krwią zbryzgana.

Niby żyjący śmiertelni ścierali się razem, walczyli

i wydzierali wzajemnie od siebie ciała poległy $\mathrm{ch}^{37}$.

Ponadto Hefajstos przedstawił rolników orzących pole, żniwa, winnicę, do której młodzi na winobranie iść będą, tańcząc przy wtórze formingi, a także wypas wołów i wreszcie taneczny korowód na łące ${ }^{38}$. Nietrudno wyczuć, jaki ideał życia bliższy jest sercu poety i bardziej jest przezeń ceniony. Gorgonie na straszliwej
36 Il., XI, 36-40.
37 Il., XVIII, 490-900.
38 Il., XVIII, 490-606. 
tarczy Agamemnona zostały poświęcone zaledwie dwa wersy, a opis obleganego miasta na tarczy Achillesa zajął tylko 31 wersów spośród 116 dotyczących scen z życia śmiertelników. Wojna nie jest zatem motywem głównym, lecz niemalże marginalnym; występuje w świecie, ale nie jest warta gloryfikacji i stawiania ponad spokojną codziennością, której Poeta poświęca o wiele więcej uwagi. Oliver Taplin, poszukując wyjaśnienia dla tak detalicznego opisu tarczy, zwraca uwagę na to, że przedstawia ona cały mikrokosmos ${ }^{39}$, uwzględnia większość istotnych dla człowieka dziedzin życia. Dwa miasta przedstawiają zderzenie czasów wojny i pokoju - pokoju, który większość z herosów porzuciła i już nigdy nie odzyska, a który umożliwia spokojny rozwój ich miast i szczęśliwe życie mieszkańców. Taplin jeszcze zauważa, że przedstawienie tarczy to zarazem moment, w którym zapadają najważniejsze dla losów Greków i Trojan decyzje: Achilles wraca do bitwy, Hektor zaś postanawia bronić swojego miasta do końca. Żaden z nich nie zazna już szczęścia, które daje życie w spokojnym, dobrze zarządzanym, nieuwikłanym w konflikty mieście, takim jak opisane w Odysei Pylos, Sparta czy wyspa Feaków. Tarcza Achillesa nie jest więc jedynie pięknym i zarazem użytecznym wyposażeniem wojownika, lecz ilustracją możliwości, które stają przed człowiekiem. Nie daje jednoznacznej odpowiedzi, który czas jest lepszy - pokoju i beztroski czy wojny i chwały; zmusza do zastanowienia się i w konsekwencji do podjęcia wyboru przez każdego ze słuchaczy z osobna ${ }^{40}$.

Koncentrując się wyłącznie na przekazie płynącym z posiadanych przez nas współcześnie dzieł z czasów starożytnej Grecji, można by dojść do mylnych wniosków. Dzieła Herodota, Tukidydesa i Ksenofonta dotyczą nade wszystko wielkich wojen. Trudno się jednak temu dziwić: Czy w oczach poetów i historyków mogły być wydarzenia bardziej godne upamiętnienia niż wielkie zmagania potężnych armii, które wywierały wpływ na charakter ówczesnego świata? Co więcej, czy mógł istnieć lepszy sposób na uwiecznienie swego imienia, niż stanie się tym, który opisał tak istotne wydarzenia? Nie oznacza to oczywiście, iż w Grecji wojny toczyły się nieprzerwanie. Poza tym poświęcenie tak znacznej uwagi historii militarnej nie świadczyło w żaden sposób o gloryfikowaniu wojny przez Greków. Była ona elementem ówczesnego życia, a często także przyczyną najważniejszych zmian społeczno-politycznych, dlatego trudno byłoby ją pominąć w narracji historycznej. Jednakże już w pierwszych dziełach literatury greckiej widoczny jest ambiwalentny stosunek twórców do wojny. Homer przedstawia jeden z najsłynniejszych mitów bohaterskich, odtwarza pieczołowicie liczne szczegóły, lecz nie głosi, iż wojna jest najlepszym sposobem rozwiązywania

39 S. Scully, op. cit., s. 4-11. Ponadto zwraca uwagę, że opis tarczy mógł nawiązywać do istniejącego przedmiotu bądź być sposobem na „rozluźnienie atmosfery” pomiędzy opisami bitew lub mimowolną dygresją poety. Ibidem, s. 3.

40 Ibidem, s. 15. 
konfliktów czy sposobem na życie. Z tego powodu trudno zgodzić się z mocną tezą zawartą przez Simone Weil w pierwszym zdaniu jej książki The Iliad, or the Poem of Force: „Prawdziwym bohaterem, prawdziwym podmiotem, centrum Iliady jest siła" ${ }^{\text {". }}$. W Iliadzie głównym jej krytykiem jest ten, którego postrzega się jako najokrutniejszego z Greków, archetyp wojownika, czyli właśnie Achilles. Jego argumentację uzupełniają wypowiedzi dwóch innych władców: Nestora i Menelaosa - zatem najmądrzejszego z Greków i tego, który miał największy powód, aby walczyć. Głoszą oni pochwałę spokojnego życia, odrzucają pragnienie wojny i chwały. Wyrażane przez nich wątpliwości oraz marzenia o innym życiu najpełniej oddają ambiwalentny stosunek Homera do wojny. Poeta nie upraszcza przy tym jej interpretacji, nie odrzuca w pełni piękna i heroizmu zmagań, ale akcentuje jej drugie, bardziej destrukcyjne oblicze ${ }^{42}$. Nie tylko ona sama nie przynosi rozwiązania, jej konsekwencje są tragiczne również dla bohaterów - większość z greckich dowódców przecież nie wróciła spokojnie do domu i dawnego życia. Wojna, co zdaje się sugerować Homer, jakkolwiek znakomicie wygląda w pieśni, w rzeczywistości nie jest niczym urokliwym czy chwalebnym. Dla zwykłego śmiertelnika prawdziwą wartością jest pokój.

\section{BIBLIOGRAFIA}

Adkins A.W.H., Values, Goals, and Emotions in the Iliad, "Classical Philology" 1982, Vol. 77(4), DOI: https://doi.org/10.1086/366728.

Arieti J.A., Achilles'Alienation in 'Iliad 9', “The Classical Journal” 1986, Vol. 82(1).

Baricco A., An Iliad, New York 2008.

Ceglarska A., Polityka i sprawiedliwość w Grecji przedsokratejskiej, Warszawa 2019.

Graves R., Mity greckie, Kraków 2012.

Homer, Iliada, Warszawa 2005.

Homer, Odyseja, Warszawa 1998.

Kubiak Z., Mitologia Greków i Rzymian, Warszawa 2003.

O Homerze i Hezjodzie, ich pochodzeniu i wspólzawodnictwie [Certamen Homeri et Hesiodi], [w:] Homeriká, czyli żywoty Homera i poematy przypisywane poecie, oprac. W. Appel, Warszawa 2007.

Scully S., Reading the Shield of Achilles: Terror, Anger, Delight, "Harvard Studies in Classical Philology" 2003, Vol. 101, DOI: https://doi.org/10.2307/3658523.

Smiley C.N., Certain Similarities in the Fundamental Thought of the Early Hebrews and the Homeric Greeks, "The Classical Journal" 1926, Vol. 21(5).

The Iliad, edited, with apparatus criticus, prolegomena, notes, and appendices by W. Leaf, London 1900.

Weil S., The Iliad, or the Poem of Force, Wallingford 1991.

${ }^{41}$ "The true hero, the true subject, the center of the Iliad is force". Zob. S. Weil, The Iliad, or the Poem of Force, Wallingford 1991, s. 3.

42 A. Baricco, An Iliad, New York 2008, s. 157. 


\section{SUMMARY}

The oldest poem of the European culture is the work dedicated to the war - Iliad. It is frequently believed that this war is the almost separate, most important heroine of the epic. This rather common opinion, that Homer would praise war and put military struggles ahead of times of peace, I would like to undermine in this work. Both in Iliad and Odyssey, there is a clear critique not only of the war itself but also more generally - of violence as a way of solving conflicts, while the times of peace and peaceful life are praised. In this article, I draw attention to various motifs presented in both epics, confirming the above thesis: statements of the heroes, presented symbolism, behavior of the gods, and finally the character of Achilles, who, while being the ideal warrior, remains also the main exponent of all doubts concerning the warfare. These doubts, as well as his wishes for another life most fully reflect Homer's ambivalent attitude to war and provoke reflection on whether the poet actually was the praising her glory, or whether he tried to express the belief in the rightness of a different way of life and conflict resolution.

Keywords: Homer; Achilles; peace; war

\section{STRESZCZENIE}

Najstarszym poematem w kręgu kultury europejskiej jest utwór poświęcony wojnie - Iliada. Panuje przekonanie, iż ta wojna jest wręcz osobną, najważniejszą bohaterką eposu. Tę dość powszechną opinię, jakoby Homer miał sławić wojnę i przedkładać zmagania wojskowe nad czasy pokoju, pragnę podważyć w niniejszej pracy. Zarówno bowiem w Iliadzie, jak i Odysei pojawia się wyraźna krytyka nie tylko samej wojny, ale i ogólniej - przemocy mającej stanowić sposób rozwiązywania konfliktów, chwalone są zaś czasy pokoju i spokojne życie. W artykule zwracam uwagę na rozmaite motywy przedstawione $\mathrm{w}$ obu eposach potwierdzające powyższą tezę (wypowiedzi bohaterów, przedstawioną symbolikę, zachowanie bogów), jak również na postać Achillesa, który będąc ideałem wojownika, pozostaje zarazem głównym wyrazicielem wszelkich wątpliwości dotyczących słuszności działań wojennych. Wyrażane przezeń wątpliwości oraz marzenia o innym życiu najpełniej oddają ambiwalentny stosunek Homera do wojny i prowokują do zastanowienia się nad tym, czy poeta rzeczywiście był piewcą jej chwały czy też starał się wyrazić przekonanie o słuszności innego sposobu życia i rozwiązywania konfliktów.

Słowa kluczowe: Homer; Achilles; wojna; pokój 